\title{
PREPARATION OF POROUS CERAMIC MATERIALS BASED ON $\mathrm{CaZrO}_{3}$
}

\author{
PRIPRAVA POROZNE KERAMIKE NA OSNOVI CaZrO3
}

\author{
Edyta Śnieżek, Jacek Szczerba, Ilona Jastrzębska, Elżbieta Kleczyk, \\ Zbigniew Pędzich
}

AGH University of Science and Technology, Faculty of Materials Science and Ceramics, al. A. Mickiewicza 30, 30-059 Krakow, Poland esniezek@agh.edu.pl

Prejem rokopisa - received: 2014-08-08; sprejem za objavo - accepted for publication: 2014-09-22

The present study was devoted to an investigation of the synthesis conditions and the influence of $\mathrm{Sn}$ ions on the production of a $\mathrm{CaZrO}_{3}$ porous structure. Porous ceramics based on $\mathrm{CaZrO}_{3}$ with a $\mathrm{SnO}$ addition were prepared by means of pressureless sintering. The study presents the influence of the type of the starting materials and the firing procedures on the microstructures of the $\mathrm{CaZrO}_{3}$ materials. Two different firing procedures were applied. The samples were obtained from pure chemical reagents $\mathrm{CaCO}_{3}$ or $\mathrm{CaO}$ and $\mathrm{ZrO}_{2}$. SnO was added in the mass fraction of $2 \%$. The prepared materials were investigated in terms of phase composition with the XRD. The microstructure was analyzed using the SEM/EDS and mercury porosimetry methods. It was found that using $\mathrm{CaCO}_{3}$ in a one-step firing process at $1650{ }^{\circ} \mathrm{C}$ with a soaking time of $10 \mathrm{~h}$ allowed us to obtain porous zirconate ceramics with a porosity of about $44 \%$. The second synthesis, where $\mathrm{CaO}$ was used, allowed us to obtain a porosity of about $36 \%$. During the firing solid solutions containing $\mathrm{Sn}$ ions in $\mathrm{CaZrO}_{3}$ and $\mathrm{ZrO}_{2}$ were formed. No other compounds containing $\mathrm{Sn}$ ions were identified. It was found that these ions played a significant role in the formation of a stable porous microstructure. The final materials mainly consisted of $\mathrm{CaZrO}_{3}$ and a small amount of $\mathrm{ZrO}_{2}$. The obtained porous CaZrO materials with an excellent oxidation and alkali resistance in a wide temperature range could be potential candidates for the use as membranes and filters.

Keywords: calcium zirconate, porous ceramics, solid solution

Ta študija je namenjena preiskavi razmer pri sintezi in vplivu ionov $\mathrm{Sn}$ na izdelavo porozne strukture $\mathrm{CaZrO}_{3}$. Porozna keramika na osnovi $\mathrm{CaZrO}_{3} \mathrm{z}$ dodatkom $\mathrm{SnO}$ je bila pripravljena s sintranjem brez tlaka. Študija predstavlja vpliv vrste izhodnega materiala in procesa žganja na mikrostrukturo materiala $\mathrm{CaZrO}_{3}$. Uporabljena sta bila dva načina žganja. Vzorci so bili izdelani iz čistih kemijskih sestavin $\mathrm{CaCO}_{3}$ ali $\mathrm{CaO}$ in $\mathrm{ZrO}_{2}$. Masni delež dodanega $\mathrm{SnO}$ je bil $w=2 \%$. Fazna sestava pripravljenega materiala je bila analizirana z rentgensko difrakcijo. Mikrostruktura je bila analizirana s SEM/EDS in s porozimetrijo z živim srebrom. Ugotovljeno je, da uporaba $\mathrm{CaCO}_{3} \mathrm{~V}$ enostopenjskem postopku žarjenja $10 \mathrm{~h}$ na $1650{ }^{\circ} \mathrm{C}$ omogoča pridobitev porozne cirkonske keramike s poroznostjo okrog $44 \%$. Druga sinteza, kjer je bil uporabljen CaO, omogoča doseganje poroznosti okrog $36 \%$. Med žganjem je nastala trdna raztopina, ki je vsebovala ione $\mathrm{Sn} v \mathrm{CaZrO}_{3}$ in $v \mathrm{ZrO}_{2}$. Ni bila ugotovljena nobena druga sestavina, ki bi vsebovala ione Sn. Navedeno je, da ti ioni igrajo pomembno vlogo pri nastanku stabilne porozne mikrostrukture.

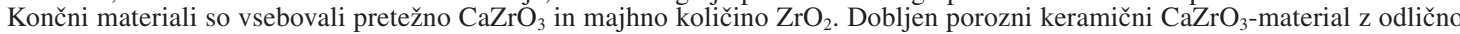
odpornostjo proti oksidaciji in alkalijam $\mathrm{v}$ širokem temperaturnem intervalu je lahko potencialni kandidat za uporabo $\mathrm{v}$ obliki membrane in filtrov.

Ključne besede: kalcijev cirkonat, porozne keramike, trdna raztopina

\section{INTRODUCTION}

Zirconate materials with a perovskite structure are interesting for many engineering fields, especially for high-temperature structural applications. Due to their characteristics they can be applied in the sensors, mechanical filters or coatings used at high temperatures and in corrosive environments. It is interesting to obtain porous materials based on calcium zirconate $\left(\mathrm{CaZrO}_{3}\right)$.

The synthesis conditions and properties of $\mathrm{CaZrO}_{3}$ can be modiefied with an addition of selected ions, such as scandium, indium, gallium, yttrium, aluminum, magnesium, etc. $\mathrm{CaZrO}_{3}$ doped with $\mathrm{Al}_{2} \mathrm{O}_{3}, \mathrm{Y}_{2} \mathrm{O}_{3}$ and $\mathrm{MgO}$ is an oxygen-ion conductor. Undoped $\mathrm{CaZrO}_{3}$ is a p-type semiconductor used at low temperatures $\left(<1200{ }^{\circ} \mathrm{C}\right)$. Moreover, trivalent cations, e.g., indium, scandium, gallium change the conduct of $\mathrm{CaZrO}_{3}$ and in this state it acts as a proton conductor. ${ }^{1-6}$

Suzuki et al. ${ }^{7}$ investigated porous, In-doped $\mathrm{CaZrO}_{3} /$ $\mathrm{MgO}$ composites with respect to the $\mathrm{CH}_{4}$-sensitivity in air. The samples were prepared from a high-purity natural dolomite, $\mathrm{ZrO}_{2}, \mathrm{In}_{2} \mathrm{O}_{3}$ and LiF. To obtain porous composites the samples were sintered in air at $1300{ }^{\circ} \mathrm{C}$. It was found that the porous composite, consisting of $\mathrm{CaZrO}_{3}, \mathrm{MgO}$ and $\mathrm{CaIn}_{2} \mathrm{O}_{4}$ (amount fraction $x=10 \%$ of $\mathrm{In}_{2} \mathrm{O}_{3}$ ), was characterized by the porosity of $57 \%$. A higher porosity $(60 \%)$ of the samples was obtained with an addition of $x=5 \%$ of $\operatorname{In}_{2} \mathrm{O}_{3}$; these samples were composed only of the $\mathrm{CaZrO}_{3}$ and $\mathrm{MgO}$ phases. The In-doping decreased the $\mathrm{CH}_{4}$-sensitivity in argon, but it was effective at improving the $\mathrm{CH}_{4}$-sensitivity in air. ${ }^{7}$ The $\mathrm{CaZrO}_{3} / \mathrm{MgO}$ composites without In obtained with the one-step heat treatment were also characterized by a 
high porosity of 30-50 \% which depended on the sintering temperature. ${ }^{8}$

The method of preparing the $\mathrm{MgO}-\mathrm{CaZrO}_{3}-\beta-$ $-\mathrm{Ca}_{2} \mathrm{SiO}_{4}$ porous materials with an interconnected porosity and a controlled size in the range of micrometers was presented in ${ }^{9}$. Dolomite-zirconia mixtures were used to obtain porous materials for refractory applications. The samples were fired in the temperature range from $800{ }^{\circ} \mathrm{C}$ to $1740{ }^{\circ} \mathrm{C}$. After the final sintering at $1740{ }^{\circ} \mathrm{C}$ the porosity was at a significant level due to the decarbonization process associated with the loss of $\mathrm{CO}_{2} \cdot{ }^{9}$

Individual properties of $\mathrm{CaZrO}_{3}$ and $\mathrm{SnO}_{2}$ may lead to an assumption that the $\mathrm{Sn}$-doped $\mathrm{CaZrO}_{3}$ has a stable porous structure. Therefore, it is interesting to study the synthesis process, the influence of the $\mathrm{Sn}$ ions on it and the structure of $\mathrm{CaZrO}_{3}$ ceramics.

\section{EXPERIMENTAL WORK}

$\mathrm{CaZrO}_{3}$ porous ceramics were prepared by means of a conventional solid-state reaction method. Calcium carbonate $\left(\mathrm{CaCO}_{3}\right)$, zirconium dioxide $\left(\mathrm{ZrO}_{2}\right)$ and tin oxide $(\mathrm{SnO})$ were used as the starting raw materials. The characteristics of the starting raw materials are presented in Table 1. The firing was carried out in two ways: $\mathrm{CaCO}_{3}$ was used with the first firing method (designation: ICZSn) and $\mathrm{CaO}$ was used with the second one (designation IICZSn). The compositions of the materials were designed taking into account the $\mathrm{CaCO}_{3}$ or $\mathrm{CaO}$ to $\mathrm{ZrO}_{2}$ ratio corresponding to the $\mathrm{CaZrO}_{3}$ stoichiometry. $\mathrm{SnO}$ was added in the mass fraction of $2 \%$. The oxides were mixed together for $2 \mathrm{~h}$. The homogenized mixtures were pressed into pellets (a diameter $20 \mathrm{~mm}$, a thickness 10 $\mathrm{mm}$ ) at a pressure of $70 \mathrm{MPa}$. The synthesis of the two

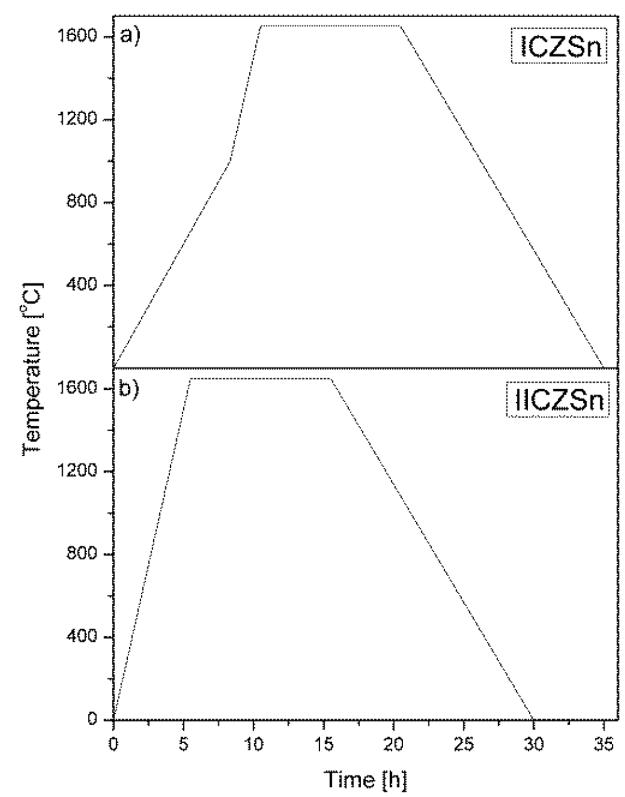

Figure 1: Firing curves: a) ICZSn, b) IICZSn Slika 1: Krivulje žganja: a) ICZSn, b) IICZSn series of the samples was carried out with pressureless sintering as shown in Figure 1. The pellets were heated up to $1650{ }^{\circ} \mathrm{C}$ with different hating rates, held at this temperature for $10 \mathrm{~h}$ and then cooled down in the furnace. Because $\mathrm{CaCO}_{3}$ was used in the first firing, the samples were heated at two different heating rates: $2{ }^{\circ} \mathrm{C} / \mathrm{min}$ up to $1000{ }^{\circ} \mathrm{C}$ and $5{ }^{\circ} \mathrm{C} / \mathrm{min}$ up to the final temperature.

Table 1: Specification of the starting materials

Tabela 1: Pregled izhodnih materialov

\begin{tabular}{|c|c|c|c|}
\hline & \multicolumn{3}{|c|}{ Reagents } \\
\cline { 2 - 4 } & $\begin{array}{c}\mathrm{CaCO}_{3} \\
(\mathrm{POCH})\end{array}$ & $\begin{array}{c}\mathrm{ZrO}_{2} \\
\text { (Acros } \\
\text { Organics) }\end{array}$ & $\begin{array}{c}\mathrm{SnO} \\
\text { (Aldrich } \\
\text { Chemistry) }\end{array}$ \\
\hline Pure $(\%)$ & 98.5 & 98.5 & 97 \\
\hline $\begin{array}{c}\text { Median particle } \\
\text { size }(\mu \mathrm{m})\end{array}$ & 41.83 & 4.53 & 23.66 \\
\hline
\end{tabular}

The phase composition of the sintered samples was examined using the powder X-ray diffraction (XRD) technique at room temperature. The measurements were performed with a Panalytical X'Pert-Pro diffractometer using $\mathrm{Cu}-K \alpha$ radiation at a $2 \theta$ angle ranging from $10^{\circ}$ to $90^{\circ}$. The obtained data were analyzed using the $X^{\prime}$ 'Pert Pro Highscore Plus software. The open porosity of the sintered samples was measured using the water-displacement method based on Archimedes' principle. The pore-size distribution was analyzed with the mercuryintrusion method (Porosimeter PoreMaster 60, Quantachrome Instruments). A cylindrical-pore model was used for the calculation. The changes in the microstructure of the products were discussed on the basis of SEM observations (NovaNanoSem 200) accompanied by an EDS chemical analysis of micro-areas.

\section{RESULTS AND DISCUSSION}

Figure 2 shows the XRD analysis of the samples. The X-ray diffraction patterns of ICZSn and IICZSn indicated that $\mathrm{CaZrO}_{3}$ in the amounts of $95 \%$ and $99 \%$, respectively, was the main phase. Cubic $\mathrm{ZrO}_{2}$ stabilized with calcium oxide $(4 \%)$ and monoclinic $\mathrm{ZrO}_{2}(1 \%)$ were identified in ICZSn. Furthermore, when $\mathrm{CaO}$ was used as the starting material (IICZSn) only cubic $\mathrm{ZrO}_{2}$ (1\%) was determined. No phases containing tin were identified. This may indicate that the $\mathrm{SnO}_{2}-\mathrm{ZrO}_{2}$ solid solution was created in accordance with reference ${ }^{10}$. An effective ionic radius of $\mathrm{Sn}^{4+}(0.069 \mathrm{~nm})$ is close to $\mathrm{Zr}^{4+}$ $(0.072 \mathrm{~nm})$ and considerably lower than $\mathrm{Ca}^{2+}(0.112$ $\mathrm{nm}) .{ }^{11}$

It is worth mentioning that, in the Sn-O system, tin oxide is present in various forms, such as $\mathrm{SnO}, \mathrm{SnO}_{2}$, $\mathrm{Sn}_{2} \mathrm{O}_{3}, \mathrm{Sn}_{3} \mathrm{O}_{4}$ and $\mathrm{Sn}_{5} \mathrm{O}_{6}$. Only $\mathrm{SnO}$ and $\mathrm{SnO}_{2}$ are stable. Above $270{ }^{\circ} \mathrm{C}, \mathrm{SnO}$ decomposes into $\mathrm{Sn}_{3} \mathrm{O}_{4}$ and metallic tin in accordance with Equation (1):

$$
4 \mathrm{SnO} \rightarrow \mathrm{Sn}_{3} \mathrm{O}_{4}+\mathrm{Sn}(1)
$$




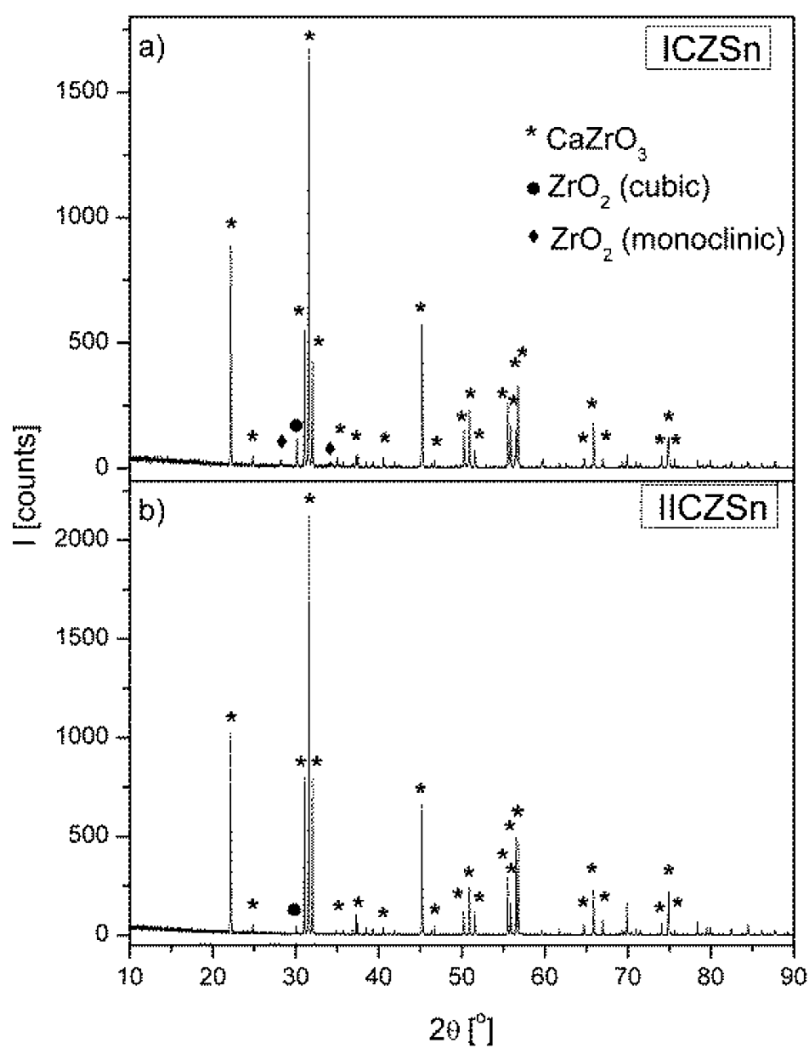

Figure 2: X-ray diffraction patterns of the samples prepared with a solid-state reaction: a) ICZSn, b) IICZSn

Slika 2: Rentgenski difrakcijski posnetek vzorcev, pripravljenih z reakcijo v trdnem: a) ICZSn, b) IICZSn

Above $450{ }^{\circ} \mathrm{C} \mathrm{Sn}_{3} \mathrm{O}_{4}$ melts incongruently into $\mathrm{Sn}$ and $\mathrm{SnO}_{2}{ }^{12,13}$

The SEM micrographs of the samples are presented in Figures 3 to 6 . The chemical compositions of the samples were confirmed with the EDS measurements (Tables 2 and 3). These allowed us to identify the most probable phase compositions of individual grains, $\mathrm{CaZrO}_{3}$ (dark grey grains - point 1) and $\mathrm{ZrO}_{2}$ (light grey phase - point 2). Figures 4 and $\mathbf{6}$ present different forms of $\mathrm{ZrO}_{2}$. In ICZSn, $\mathrm{ZrO}_{2}$ created clearly identifiable

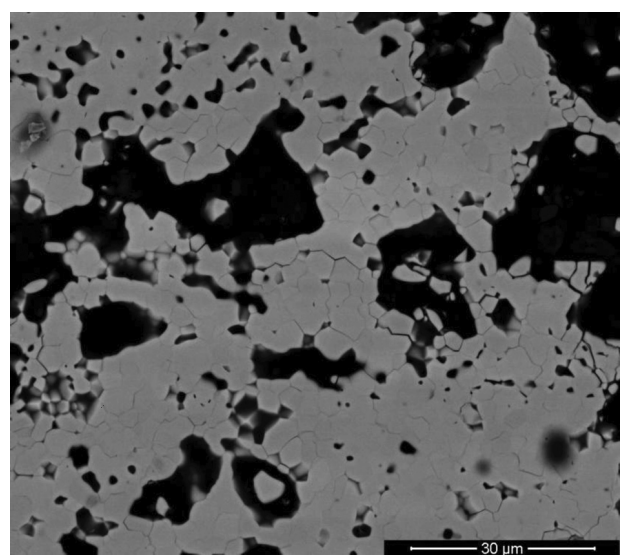

Figure 3: SEM micrograph of the ICZSn microstructure Slika 3: SEM-posnetek mikrostrukture ICZSn

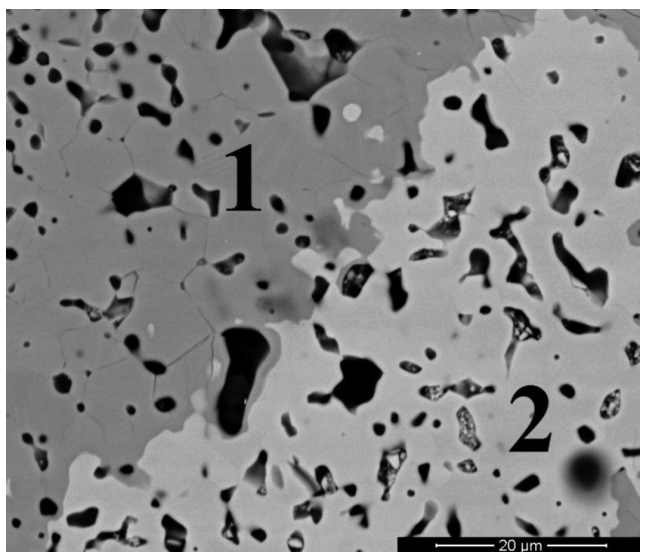

Figure 4: SEM micrograph of the ICZSn sample with marked points where the EDS analysis was performed

Slika 4: SEM-posnetek mikrostrukture vzorca ICZSn z označenima točkama, kjer je bila izvršena EDS-analiza

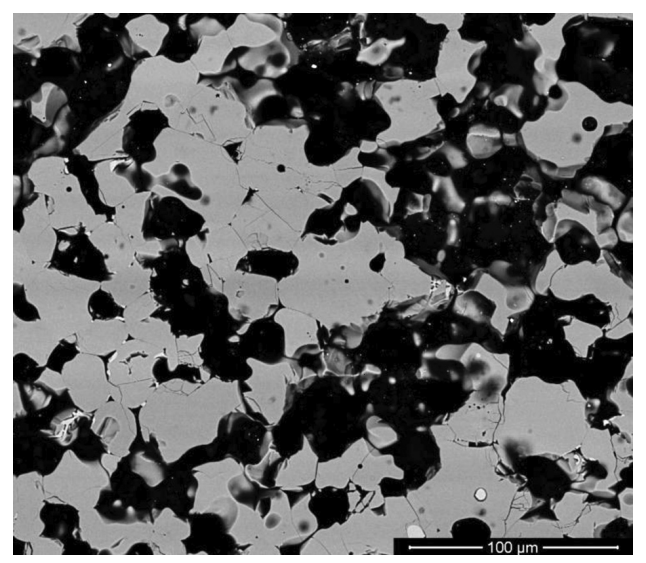

Figure 5: SEM micrograph of the IICZSn microstructure Slika 5: SEM-posnetek mikrostrukture IICZSn

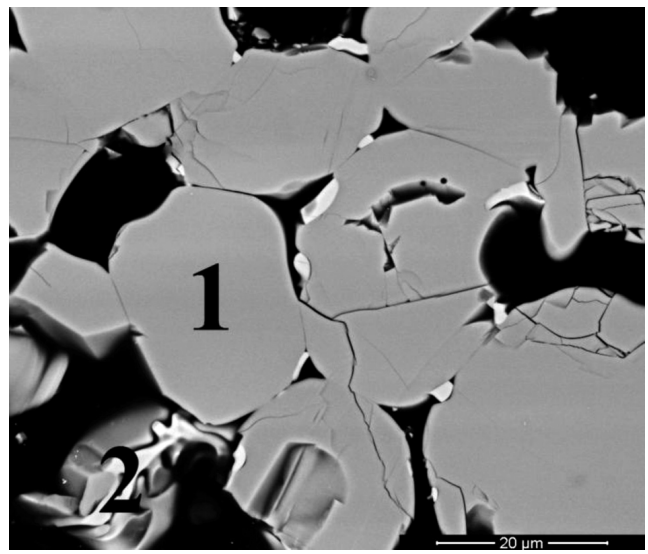

Figure 6: SEM micrograph of the IICZSn sample with marked points where the EDS analysis was performed

Slika 6: SEM-posnetek mikrostrukture vzorca IICZSn z označenima točkama, kjer je bila izvršena EDS-analiza

areas. In IICZSn, $\mathrm{ZrO}_{2}$ occurred as individual inclusions. This can be explained with a higher concentration of $\mathrm{ZrO}_{2}$ in the ICZSn samples (5\%). Furthermore, it can be established that the $\mathrm{Sn}$ ions incorporated in $\mathrm{CaZrO}_{3}$ and 


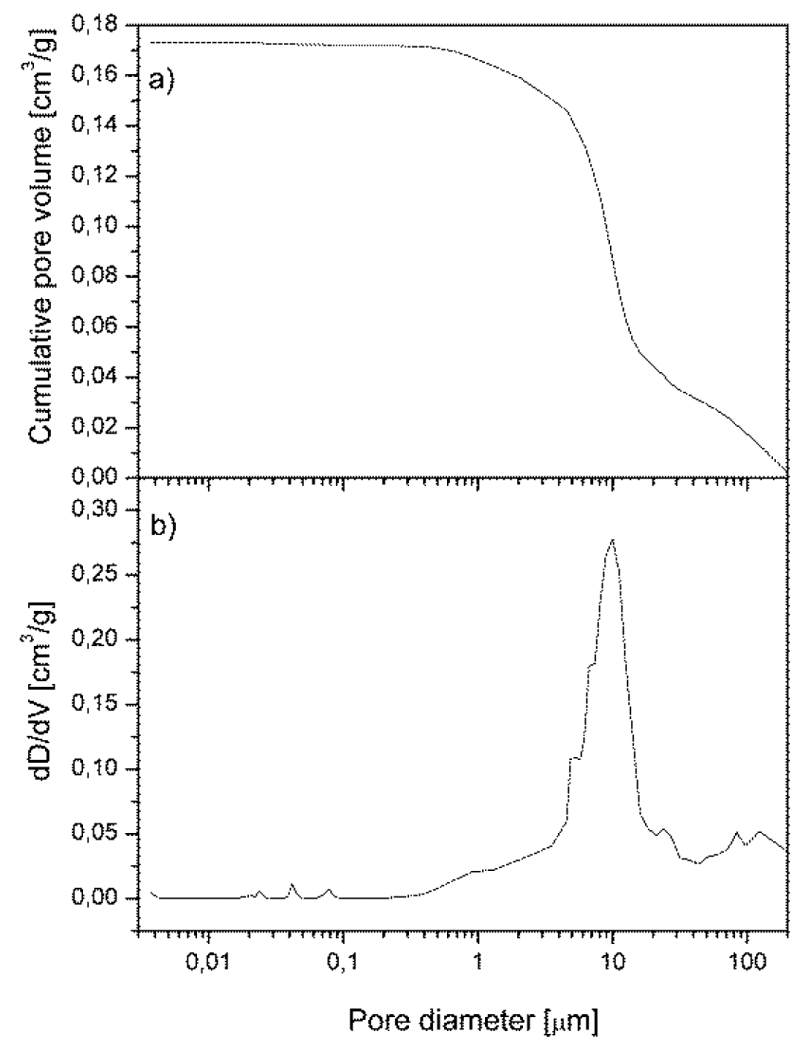

Figure 7: a) Cumulative pore-volume changes and b) pore-size distribution (pore-frequency curve) of the ICZSn sample

Slika 7: a) Kumulativna sprememba volumna por in b) razporeditev velikosti por (krivulja frekvence por) vzorca ICZSn

$\mathrm{ZrO}_{2}$ are in different amounts. The SEM/EDS investigations confirmed the results of the XRD analysis. The average diameter of the $\mathrm{CaZrO}_{3}$ grains changed from about $5-15 \mu \mathrm{m}$ for ICZSn to 50 for IICZSn. The grain growth was associated with the type of the used raw material $\left(\mathrm{CaCO}_{3}-\mathrm{ICZSn}\right.$ or $\left.\mathrm{CaO}-\mathrm{IICZSn}\right)$. Moreover, when only small amounts of $\mathrm{ZrO}_{2}$ were observed in the samples (IICZSn - $1 \%$ ) the $\mathrm{Sn}$ ions were incorporated into the $\mathrm{CaZrO}_{3}$ structure.

Table 2: Average chemical compositions (EDS) of $\mathrm{CaZrO}_{3}$ and $\mathrm{ZrO}_{2}$ grains according to Figure 4

Tabela 2: Povprečna kemijska sestava (EDS) $\mathrm{CaZrO}_{3}$ in $\mathrm{ZrO}_{2} \mathrm{zrn}$, skladno s sliko 4

\begin{tabular}{|c|c|c|c|c|}
\hline Point & \multicolumn{4}{|c|}{ Amount fraction, $x$ (ICZSn)/\% } \\
\hline & $\mathrm{O}$ & $\mathrm{Zr}$ & $\mathrm{Sn}$ & $\mathrm{Ca}$ \\
\hline 1 & 53.9 & 23.8 & 0.4 & 21.9 \\
\hline 2 & 57.9 & 33.6 & 0.7 & 7.8 \\
\hline
\end{tabular}

Table 3: Average chemical compositions (EDS) of $\mathrm{CaZrO}_{3}$ and $\mathrm{ZrO}_{2}$ grains according to Figure 6

Tabela 3: Povprečna kemijska sestava (EDS) $\mathrm{CaZrO}_{3}$ in $\mathrm{ZrO}_{2}$ zrn, skladno s sliko 6

\begin{tabular}{|c|c|c|c|c|}
\hline Point & \multicolumn{4}{|c|}{ Amount fraction, $x$ (IICZSn)/\% } \\
\hline & O & $\mathrm{Zr}$ & $\mathrm{Sn}$ & $\mathrm{Ca}$ \\
\hline 1 & 51.1 & 24.5 & 0.9 & 23.5 \\
\hline 2 & 62.2 & 29.9 & 0.2 & 7.7 \\
\hline
\end{tabular}

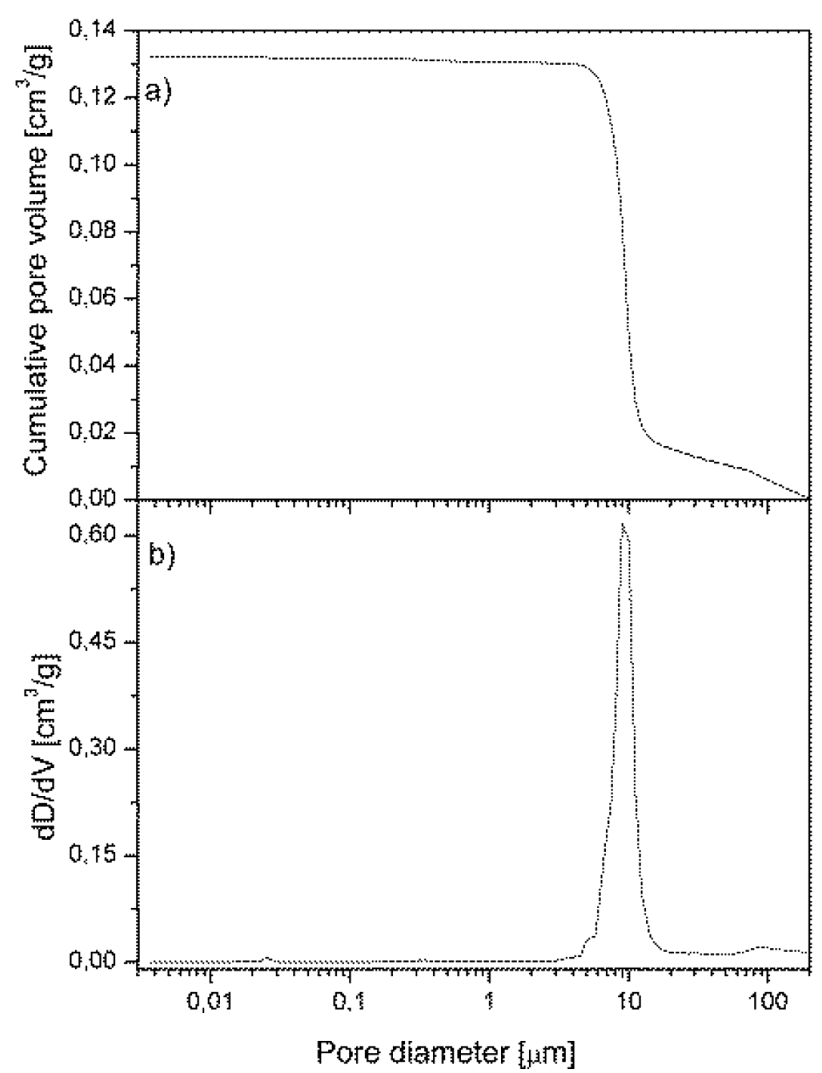

Figure 8: a) Cumulative pore-volume changes and b) pore-size distribution (pore-frequency curve) of the IICZSn sample

Slika 8: a) Kumulativna sprememba volumna por in b) razporeditev velikosti por (krivulja frekvence por) vzorca IICZSn

Table 4: Properties of ICZSn and IICZSn materials determined with mercury porosimetry

Tabela 4: Lastnosti materialov ICZSn in IICZSn, določene s porozimetrijo z živim srebrom

\begin{tabular}{|c|c|c|c|c|}
\hline & $\begin{array}{c}\text { Cumulative } \\
\text { pore } \\
\text { volume } \\
\mathrm{mm}^{3} / \mathrm{g}\end{array}$ & $\begin{array}{c}\text { Median } \\
\text { pore } \\
\text { diameter } \\
\mu \mathrm{m}\end{array}$ & $\begin{array}{c}\text { Bulk } \\
\text { density } \\
\mathrm{g} / \mathrm{cm}^{3}\end{array}$ & $\begin{array}{c}\text { Porosity } \\
\%\end{array}$ \\
\hline ICZSn & 173.6 & 10 & 2.49 & 43.2 \\
\hline IICZSn & 132.3 & 9 & 2.84 & 37.6 \\
\hline
\end{tabular}

The total pore volume and the median pore diameter of the samples analyzed with the mercury-intrusion method are shown in Figures $\mathbf{7}$ and $\mathbf{8}$ and summarized in Table 4. The figures show slightly different types of curves but having the same mean pore size. The ICZSn sample (Figure 7) was characterized by one main pore population of about $10 \mu \mathrm{m}$ in diameter. Two other populations were also distinctly detectable: of less than 0.1 $\mu \mathrm{m}$ and of about $100 \mu \mathrm{m}$. In contrast, the IICZSn sample had a very narrow pore-size distribution with the mean size of $9 \mu \mathrm{m}$ (Figure 8). This proved that, in this case, the pores were more uniform and monomodal. This difference may have resulted from the $\mathrm{CaCO}_{3}$ decarbonization which occurred, as generally known, in the $600-950{ }^{\circ} \mathrm{C}$ temperature range. During the heating, 
$\mathrm{CaCO}_{3}$ decomposed into $\mathrm{CaO}$ (solid) and $\mathrm{CO}_{2}$ (gas) according to Equation (2). The formed $\mathrm{CaO}$ reacted with $\mathrm{ZrO}_{2}$ creating $\mathrm{CaZrO}_{3}$.

$$
\mathrm{CaCO}_{3} \rightarrow \mathrm{CaO}+\mathrm{CO}_{2} \uparrow
$$

The porosity measured in accordance with Archimedes' principle varied from $44 \%$ to $35 \%$ for ICZSn and IICZSn, respectively, being in good agreement with the results of the mercury-intrusion analysis.

These porous materials, being comprised of $\mathrm{CaZrO}_{3}$ and a small amount of $\mathrm{ZrO}_{2}$ have an excellent oxidation and alkali resistance in a wide temperature range. The presented materials can be used as filters, membranes and insulation materials. Moreover, an incorporation of Sn ions in the $\mathrm{CaZrO}_{3}$ and $\mathrm{ZrO}_{2}$ structure can lead to obtaining unique electrical properties.

\section{CONCLUSIONS}

The article focuses on porous $\mathrm{CaZrO}_{3}$ materials with $\mathrm{SnO}$ additions. The presented results describe the influence of the starting raw materials and the firing procedure on the final properties of the $\mathrm{CaZrO}_{3}$ ceramics. It is shown that using $\mathrm{CaCO}_{3}$, in comparison with $\mathrm{CaO}$, allowed us to obtain a material with the porosity exceeding $40 \%$. A porous structure can be controlled by the synthesis conditions.

During the firing solid solutions containing $\mathrm{Sn}$ ions were formed in $\mathrm{CaZrO}_{3}$ and $\mathrm{ZrO}_{2}$. The final materials ICZSn and IICZSn were composed of about $95 \%$ and $99 \%$ of $\mathrm{CaZrO}_{3}$, respectively, and $\mathrm{ZrO}_{2}$. No free $\mathrm{CaO}$ or Sn-containing inclusions (expect for the $\mathrm{CaZrO}_{3}$ solid solution) were detected with the performed XRD and SEM/EDS analyses. Porous $\mathrm{CaZrO}_{3}$ materials could be potential candidates for the use as membranes and filters.
Moreover, a $\mathrm{CaZrO}_{3}$ structure with incorporated $\mathrm{Sn}$ ions can reveal unique electrical properties.

\section{Acknowledgement}

The work was partially supported by the grant no. INNOTECH-K2/IN2/16/181920/NCBR/13.

\section{REFERENCES}

${ }^{1}$ C. C. Wang, S. A. Akbar, W. Chen, J. R. Schorr, Sens. Actuators A, 58 (1997), 237-243, doi:10.1016/S0924-4247(97)01394-0

${ }^{2}$ C. Wang, W. H. Chen, S. A. Akbar, J. Mater. Sci., 32 (1997), 2305-2312, doi:10.1023/A:1018580418264

${ }^{3}$ K. Kobayashi, S. Yamaguchi, Y. Iguchi, Solid State Ionics, 108 (1998), 355-362, doi:10.1016/S0167-2738(98)00063-0

${ }^{4}$ C. S. Prasanth, H. Padma Kumar, R. Pazhani, S. Solomon, J. K. Thomas, J. Alloys Compd., 464 (2008), 306-309, doi:10.1016/ j.jallcom.2007.09.098

${ }^{5}$ S. C. Hwang, G. M. Choi, Solid State Ionics, 177 (2006), 3099-3103, doi:10.1016/j.ssi.2006.08.002

${ }^{6}$ V. Longo, F. Marchini, F. Ricciardiello, A. de Pretis, La Ceramica, 34 (1981), 23-28

${ }^{7}$ Y. Suzuki, M. Awano, N. Kondo, T. Ohjo, J. Eur. Ceram. Soc., 22 (2002), 1177-1182, doi:10.1016/S0955-2219(01)00405-8

${ }^{8}$ Y. Suzuki, P. E. D. Morgan, T. Ohjo, J. Am. Ceram. Soc., 83 (2000), 2091-2093, doi:10.1111/j.1151-2916.2000.tb01519.x

${ }^{9}$ J. L. Rodrígues, M. A. Rodríguez, S. De Aza, P. Pena, J. Eur. Ceram. Soc., 21 (2001), 343-354, doi:10.1016/S0955-2219(00)00212-0

${ }^{10}$ B. Gaillard-Allemand, R. Podor, M. Vilasi, Ch. Rapin, A. Maitre, P. Steinmetz, J. Eur. Ceram. Soc., 22 (2002), 2297-2303, doi:10.1016/ S0955-2219(02)00034-1

${ }^{11}$ R. D. Shannon, Acta Crystallogr. A, 32 (1976), 751-767, doi:10.1107/S0567739476001551

${ }^{12}$ G. H. Moh, Chem. Erde, 33 (1974), 243-275

${ }^{13}$ S. Cahen, N. David, J. M. Fiorani, A. Maitre, M. Vilasi, Thermochim. Acta, 403 (2003), 275-285, doi:10.1016/S0040-6031(03) 00059-5 